\title{
TANTANGAN PEMBELAJARAN DI ERA NEW NORMAL
}

\author{
RAUDHATUL JANNAH
}

1810128220031@mhs.ulm.ac.id

\begin{abstract}
Abstrak
Dunia pendidikan adalah satu bidang yang berperan dalam membangun keyakinan, pemahaman, wawasan, serta perilaku manusia. Secara garis besar, di sinilah umat manusia menemukan pelajaran dan mampu mengembangkan potensi diri peserta didiknya. Corona virus Desease-19 atau yang lebih kita kenal dengan Covid-19 yang telah berhasil mengubah cara belajar dan mengajar semua kalangan tidak hanya dalam negeri bahkan sampai ke mancanegara. Berkaca dari adanya pandemi ini kita memahami bahwa sebenarnya tidak ada yang dapat menghalangi transfer ilmu pengetahuan, sekalipun kemunculan virus yang menggemparkan. Dalam beberapa minggu terakhir, muncul kebijakan baru yaitu New Normal dan tentunya berdampak pada beberapa bidang didalamnya termasuk bidang Pendidikan, berbagai kebijakan pendidikan dilakukan berkenaan dengan hal tersebut.
\end{abstract}

Kata Kunci: Pendidikan, Covid-19, New Normal

\section{PENDAHULUAN}

Telah diketahui bersama bahwa pendidikan adalah upaya mencerdaskan kehidupan bangsa dan meningkatkan kualitas manusia Indonesia yang berjiwa kebangsaan, cinta tanah air, berakhlak mulia. Sejak zaman dahulu kita sudah mendapatkan pendidikan melalui lembaga-lembaga pendidikan yang ada di tempat kita, baik itu pendidikan formal, informal, maupun nonformal. Kita menempuh jenjang pendidikan dimulai dari yang paling dini ada Pendidikan Anak Usia Dini, Taman Kanak-Kanak, kemudian Sekolah Dasar, berlanjut ke Sekolah Menengah Pertama, Sekolah Menengah Atas, sampai ke Perguruan Tinggi.

Proses belajar mengajar pada umumnya dilakukan didalam ruang kelas yang terdiri atas guru dan peserta didik dengan jumlah lebih kurang 20 orang disetiap kelas dan kegiatan seperti itu sudah berlangsung sejak pertama kali ada keberadaan sekolah di Indonesia. Terlepas dari hal itu semua, tidak dapat dipungkiri, saat dunia mengalami keadaan yang katakanlah mampu merubah tatanan hidup yang semula biasa saja tanpa adanya peraturanperaturan khusus terkait cara hidup di dalam dan diluar rumah.

Virus yang hadir sejak Desember lalu pertama kali ditemukan di Wuhan,China berhasil menggemparka dunia dan tentunya penyebaran virus yang luar biasa mengakibatkan negara-negara di dunia menerapkan Lock Down, Work From Home sehingga berpengaruh 
pada proses belajar mengajar yang berbeda pada umumnya, bakan dari semua tingkat satuan pendidikan sampai perguruan tinggi. "Ketakutan menyeruak mengguncang tonggak-tonggak kepercayaan diri. Doa syahdu tanpa suara tidak mampu mengusir rasa takut. Tidak dapat tidak, kondisi tersebut karena bacaan. Bacaan tentang covid-19 mengudak-aduk pikiran dan perasaan sejak kasus Wuhan melejit. Halnya semakin menjadi, ketika kuliah memberi informasi atas covid-19 agar mahasiswa waspada. Covid-19 musuh utama manusia, karena itu mari lawan bersama. Kita bangsa petarung. Sungguh heroik. Kalau belakangan, berdamai menjadi pilihan, soal proses.Badan terasa panas, tengorokkan berasa tercekik, dan nafas ikutikutan bak berasa tersendat. Bukankah ketiga hal tersebut pertanda sapaan covid-19? "(Ersis Warmansyah, 2020:23 )

Kemudian, apakah hanya cukup sampai di pikiran saja? Tentu kisah pandemi apalagi menyangkut pendidikan akan menjadi sejarah suatu hari nanti. Untuk dapat menulis, Dalam konteks menulis, akan sangat mendukung kalau informasi yang diinput sebagaimana adanya (Ersis WA, 2020:5)

Covid-19 memang merupakan virus hebat yang berhasil mengubah tatanan hidup manusia diseluruh penjuru dunia. Di Indonesia sendiri Virus covid-19 mulai masuk pada bulan Maret dan pertengahan Maret mulailah muncul hashtag \#Dirumahaja dan akhirnya berlangsung sampai hari ini, setelah sekitar 5 bulan negara kita terdampak kasus positif covid -19 kemudian pemerintah menerapkan kebijakan baru yang disebut New Normal atau Normal baru yang tentunya memberikan dampak ke berbagai sektor kehidupan termasuk pendidikan.

\section{PEMBAHASAN}

Pendidikan sebagai proses pembelajaran untuk mencapai pencapaian berupa kedewasaan, baik dalam segi perilaku maupun dalam kehidupan sehari-hari, mendorong seseorang menjadi warga negara yang baik, sadar tehadap tata cara hidup bermasyarakat. Dengan demikian dapat diketahui bahwa pendidikan adalah bagian dari sebuah proses pembudayaan dan merupakan upaya masyarakat untuk keberlangsungan tradisinya, pendidikan adalah sebuah proses melalui kebudayaan yang mengontrol masyarakat.( Subiyakto, B., \& Mutiani, M. 2019)

Ada berbagai metode pembelajaran dan berbagai sumber-sumber pembelajaran yang ada yang digunakan di dalam dunia pendidikan. Metode merupakan cara yang digunakan guru dalam mengimplementasikan rencana pembelajaran yang telah disusun dan merupakan alat untuk mencapai tujuan pembelajaran. Metode pembelajaran merupakan satu komponen 
pembelajaran yang harus digunakan dalam setiap kegiatan pembelajaran karena untuk mencapai tujuan pembelajaran maupun dalam upaya membentuk kemampuan peserta didik diperlukan adanya suatu metode atau cara mengajar yang efektif. (Syaharuddin, S., \& Mutiani, M. 2020).

Metode yang sesuai dengan pembelajaran di implementasikan guru saat mengajar di sekolah. Sekolah adalah tempat transfer ilmu pengetahuan melalui kegiatan belajar mengajar yang di dalamnya peserta didik diajarkan oleh guru dengan menggunakan metode yang telah dipersiapkan oleh guru bersangkutan.

Ketika ada metode pembelajaran tentunya dalam komponen pembelajaran ada yang namanya sumber belajar. sumber belajar sangatlah penting dalam komponen belajar, karena melalui sumber belajar ini lah peserta didik dapat memperoleh informasi yang berkaitan dengan materi yang akan mereka pelajari (Syaharuddin, S., Hidayat Putra, M. A., \& Susanto, H. 2019). Contoh dari sumber belajar misalnya : Nilai-nilai haul guru sekumpul sebagai sumber belajar IPS.

Pada konteks Ilmu Pengetahuan Sosial (IPS), nilai-nilai yang terkandung dalam haul guru sekumpul merupakan bagian dari pendidikan, Haul guru sekumpul dapat dijadikan sebagai sumber belajar IPS dikarenakan banyak nilai-nilai positif yang terdapat di dalam aktivitas kegiatan tersebut sesuai dengan tujuan Pendidikan IPS. (Nasih, M., Abbas, E. W., \& Syaharuddin, S. 2019) .Peningkatan kualitas pembelajaran di sekolah dipengaruhi banyak faktor. Faktor tersebut bisa dilihat dari: guru, peserta didik, sarana dan prasarana, lingkungan, dan manajemennya. (Mutiani,2020).

Selain mengajar di kelas, kalau pengajar di perguruan tinggi atau dosen juga memiliki tugas lain. Dalam ranah pendidikan dan pengajaran, tugas seorang dosen adalah menerjemahkan kurikulum artinya membuat kerangka materi perkuliahan, mendesain pembelajaran sampai dengan mengevaluasi. (Ersis Warmansyah,2020:3).

Dewasa ini, teknologi dan informasi mempengaruhi aktivitas sekolah dengan sangat masif. Pendidikan mengalami pergolakan yang sangat dahsyat. Peran guru yang selama ini menjadi sebagai satu-satunya penyedia ilmu pengetahuan sedikit banyaknya telah bergeser. Seiring berjalannya waktu, kini peran dan kehadiran guru kelas jadi semakin menantang dan memerlulan tingkat kreativitas yang sangat tinggi. (Negara, H. R. P., Syaharuddin, S., Kurniawati, K. R. A., Mandailina, V., \& Santosa, F. H. 2019).

Terlepas dari perkembangan Teknologi dan Informasi, ada banyak kebijakan terkait pendidikan di Indonesia, salah satunya adalah sistem zonasi. Sistem Zonasi merupakan penataan reformasi Pembagian jarak wilayah Sekolah. (Mutiani, M., Subiyakto, B., Jumriani, 
J., Aslamiah, A., \& Afrina, A. 2019).

Sistem Zonasi yang mengatur tentang zona wilayah bagi calon peserta didik dimuat dalam Sistem PPDB yang baru melalui Permendikbud No.14 Tahun 2018. Sistem zonasi terbaru ini prinsipnya hampir sama dengan Sistem Bina lingkungan, hanya saja pada jumlah kuota sistem zonasi ini jauh lebih banyak dibandingkan bina lingkungan yaitu mencapai 90\%. (Mutiani, M., Subiyakto, B., Jumriani, J., Aslamiah, A., \& Afrina, A. 2019).

Berdasarkan hal-hal diatas, ada membahas mengenai perkembangan teknologi yang mempengaruhi proses belajar serta adanya kebijakan baru yang dapat menghapuskan status sekolah yang menjadi skolah unggulan, karena akan tidak ada beda nya karena peserta didiknya diterima berdasarkan jarak tempat tinggalnya dengan sekolah terdekat. Mengenai pembelajaran berbasis teknologi menurut saya peserta didik memang senang dengan adanya teknologi seperti itu serta dapat meningkatkan minatnya, artinya peserta didik sudah diantisipasi ketika ada kemungkinan pembelajaran jarak jauh walaupun tidak pernah diduga sebelumnya bahkan siapapun tidak ada yang menduganya. Kehadiran virus covid-19 di Indonesia sedikit banyaknya mengubah tatanan pendidikan, mulai dari cara belajar sampai cara penerimaan peserta didik baru.

Ketika COVID-19 mewabah hingga ke Indonesia dan memuncak pada pertengahan Maret 2020, pemerintah kita mengeluarkan satu kebijakan yaitu WFH (work from home) agar virus ini tidak menyebar secara cepat dan menyeluruh. Respon dari dunia pendidikan adalah belajar secara online atau daring. Beralih cara belajar di kampus ke rumah sebagai akibat dari kebijakan WFH agar social and fisical distancing bisa terlaksana dan dapat mengurangi penyebaran virus tersebut.

Terdapat banyak kendala yang dialami, mulai dari masalah teknis hingga proses belajar mengajar, seperti tersedia dan tidaknya jaringan, biaya kouta yang cukup mahal, mengoperasionalkan aplikasi (zoom, google meet, google calassroom) dengan prosedur yang benar, contohnya dengan tidak menghidupkan mute (microphone) saat mendengarkan materi agar tidak tersdengar storing, cara menampilkan PPT/dokumen dengan tepat, dan masih rendahnya partisipasi dari mahasiswa di dalam pembelajaran. (Syaharuddin, S. 2020)

Dampak pandemi yang telah berhasil mengubah tata cara belajar bukanlah hal yang dapat menghalangi seseorang untuk terus mendapatkan pendidikan, artinya kesiapan belajar daring sudah dimulai sebelum adanya wabah terbaru di tahun 2020 ini,ini hanyalah praktik pembelajaran dengan teknologi informasi yang berlangsung cukup lama dibandingkan biasanya, yang biasanya hanya dipakai di beberapa materi pembelajaran tertentu, tetapi kali ini direalisasikan di setiap proses pembelajaran. 


\section{SIMPULAN}

Pendidikan sebagai sebuah langkah untuk mencapai kedewasaan, baik dalam segi perilaku maupun dalam kehidupan sehari-hari, mampu mendorong seseorang menjadi warga negara yang baik, dan sadar tehadap tata cara hidup di masyarakat. Berbagai tatanan pendidikan dilaksanakan terkait cara yang sesuai untuk keberlangsungan proses belajar dan mengajar hingga adanya kebijakan sistem zonasi di negara kita.

Terkhusus pula karena adanya tantangan pandemi Covid-19, sebelumnya pernah dilaksanakan pembelajaran di dalam kelas dengan menggunkan media teknologi yang bisa di akses melalui android, sesudah adanya pandemi hingga diterapkannya era normal baru, justru kebijakan yang awalnya dirasa memicu antusias peserta didik justru menjadi tantangan baru yang mau tidak mau harus dilakukan.

\section{DAFTAR PUSTAKA}

Abbas, E. W. (2015). Pendidikan IPS Berbasis Kearifan Lokal. WAHANA Jaya Abadi.

Abbas, E. W. (2020). Menulis Artikel Jurnal. Menulis Artikel Jurnal.

Abbas, E. W. (2020). Menulis di Otak dan Menuliskan Tulisan di Otak.

Mutiani, M., Subiyakto, B., Jumriani, J., Aslamiah, A., \& Afrina, A. (2019). Laporan : Relevansi Modal Sosial Dalam Pembelajaran IPS (Studi Kasus Dalam Sistem Zonasi Di Smp Negeri Kota Banjarmasin).

Mutiani, M., WARMANSYAH ABBAS, E. R. S. I. S., Syaharuddin, S., \& Susanto, H. (2019). Penerapan Transcript Based Lesson Analyses (TBLA) Sebagai Upaya Peningkatan Pembelajaran Sejarah Di Sma Negeri 7 Banjarmasin.

Nasih, M., Abbas, E. W., \& Syaharuddin, S. (2019). NILAI-NILAI HAUL GURU SEKUMPUL SEBAGAI SUMBER BELAJAR IPS. Jurnal Socius, 8(2).

Negara, H. R. P., Syaharuddin, S., Kurniawati, K. R. A., Mandailina, V., \& Santosa, F. H. (2019). Meningkatkan Minat Belajar Siswa Melalui Pemanfaatan Media Belajar Berbasis Android Menggunakan Mit App Inventor. SELAPARANG Jurnal Pengabdian Masyarakat Berkemajuan, 2(2), 42-45.

Subiyakto, B., \& Mutiani, M. (2019). Internalisasi nilai pendidikan melalui aktivitas masyarakat sebagai sumber belajar ilmu pengetahuan sosial. Khazanah: Jurnal Studi Islam dan Humaniora, 17(1), 137-166.

Syaharuddin, S. (2020). PEMBELAJARAN MASA PANDEMI: DARI KONVENSIONAL KE DARING. PEMBELAJARAN MASA PANDEMI: DARI KONVENSIONAL KE 


\section{DARING.}

Syaharuddin, S., \& Mutiani, M. (2020). STRATEGI PEMBELAJARAN IPS: Konsep dan Aplikasi.

Syaharuddin, S., Hidayat Putra, M. A., \& Susanto, H. (2019). Nilai Budaya Manyambang Masyarakat Desa Lok Baintan Dalam Sebagai Sumber Belajar IPS.

WARMANSYAH ABBAS, E. R. S. I. S. (2020). Menulis di Era Covid-19: Memanage Trauma Psikologis Menghindari Psikosomatis. Menulis di Era Covid-19: Memanage Trauma Psikologis Menghindari Psikosomatis. 